\title{
Religiosity and Entrepreneurial Intentions in Nigeria
}

\author{
Joseph David ${ }^{1 *}$, Musa Clement Lawal ${ }^{2}$ \\ Ibrahim Badamasi Babangida University Lapai, Niger State, Nigeria \\ 1josephdavid970@gmail.com, ${ }^{2}$ kuburshosho@gmail.com \\ ${ }^{*}$ Corresponding author
}

\begin{abstract}
In assessing the influence of religiosity on entrepreneurial intention, and considering other factors such as family entrepreneurial background, personal attitude towards entrepreneurship, societal norms and perceived self-efficacy, the study employed Logistics regression model to analyze 100 cross-sectional data obtained from graduates and undergraduates of economics and business administration. The empirical result indicates that religiosity influence entrepreneurial intentions positively. Equally, the demonstrate the presence of a positive relationship between personal attitude towards entrepreneurship and societal norms, and a negative correlation between self-efficacy and entrepreneurial intentions. The intensity of religious teachings towards enhancing moral values in business and entrepreneurial intentions and the provision of loans and creation of enabling a business environment for intending entrepreneurs therefore recommended.
\end{abstract}

Keywords: religiosity, entrepreneurial intention, logit model

\begin{abstract}
Abstrak
Dalam menilai pengaruh religiusitas pada niat kewirausahaan, dan mempertimbangkan faktor-faktor lain seperti latar belakang kewirausahaan keluarga, sikap pribadi terhadap kewirausahaan, norma-norma kemasyarakatan dan persepsi self-efficacy, penelitian ini menggunakan model regresi logistik untuk menganalisis 100 data cross-sectional yang diperoleh dari lulusan dan mahasiswa sarjana ekonomi dan administrasi bisnis. Hasil empiris menunjukkan bahwa religiusitas mempengaruhi niat kewirausahaan secara positif. Sama, menunjukkan adanya hubungan positif antara sikap pribadi terhadap kewirausahaan dan norma-norma kemasyarakatan, dan korelasi negatif antara self-efficacy dan niat kewirausahaan. Intensitas ajaran agama terhadap peningkatan nilai-nilai moral dalam bisnis dan niat kewirausahaan, dan penyediaan pinjaman dan penciptaan memungkinkan lingkungan bisnis untuk pengusaha yang ingin direkomendasikan.
\end{abstract}

Kata kunci: religiusitas, niat berwirausaha, model logit

\section{Cara Mengutip:}

David, J., \& Lawal, M. C. (2018). Religiosity and Entrepreneurial Intentions in Nigeria. Esensi: Jurnal Bisnis dan Manajemen. Vol.8 (2): 211 - 222. doi: 10.15408/ess.v8i2.7331. 


\section{INTRODUCTION}

Despite the common challenges of risk-bearing, uncertainties, failure in decision making and barriers in entrepreneurship, which are likely to retard the growth of an entrepreneur's business (Nandan, 2007), people still have the determination or intention to become entrepreneurs. Hence, the very act of becoming an entrepreneur is not fate but a decision made by individuals. Although research has shown that factors such as education, caste, family and social background, previous employment, gender, ethnic membership (Kothari, 2013; Tiwari et al., 2017) influence entrepreneurial intentions, religion seems to regard as the major influencing factor of entrepreneurial intentions. This fact happened because religion influences the values, attitude, behaviors, a way of life, and the decision making of the people (in term of entrepreneurial decision making and job selection) both at individual and societal levels (Dodd and Seaman, 1999; Khraim, 2010; Oukil, 2013; Safiek, 2009).

Since the personal belief and attitude of a person towards setting up new business forms the fundamental nascent-factors of entrepreneurship (Muhammad, et al 2015), as such, religious beliefs which strongly influences personal beliefs provides strong incentives to follow moral values such as trust, honesty, benevolence, and restraint from violence (Alkire, 2006), which are evitable prerequisite to be successful in a business. Religious people tend to have good traits and be trustworthy (Deneulin and Rakodi, 2011), which are the greatest asset in the business world. Accordingly, religious people are discouraged from engaging in activities such as non-payment of debt, hence treating these activities as sinful. Hence, they have a stronger personal attitude towards entrepreneurial activity than perceived behavior control compared to irreligious group (Wibowo, 2017).

There exist no specific religion or culture for entrepreneurship, for it cuts across all religion and diverse socio-cultural settings, each of which represents a symbol of global entrepreneurial behavior (Valliere, 2008; Riaz et al., 2016). Apart from determining the beliefs of people (Bwisa and Ndolo, 2011) and affecting the values of individuals positively through perseverance, honesty, bravery, foresightedness and general standards, religion also plays a significant role in motivating people to take up entrepreneurial activities. Explicitly, some aspects of religious beliefs are responsible for the shaping of people's motivations towards business development. Thus as seen in the Western economy in which religion was responsible in forming the basis for the rise of Capitalism (Weber, 1922), business could be rightly said to be a religiously valued endeavor. The likelihood of being religious have a stronger influence on people, especially on personal attitude towards entrepreneurial activity, compared to the irreligious group of people (Wibowo, 2017).

Concerning religions such as Christianity and Islam, entrepreneurship is highly encouraged. For instance, from the context of Islam, the desire to be financially independent or the intention of entrepreneurial activities is usually motivated by the figure of Prophet Muhammad (Peace and blessings be upon him) himself who was a quite successful merchant/ businessman in his young age before he became a prophet. He was known for integrity, and he bore the honorific title, the trustworthy. The Quran states: "God has made business lawful for you." In some Hadith of the Prophet Muhammad (PBUH), he advocated for trade that he described as a profession that has the most lucrative and extensive sustenance. Consequently, trade and commerce have always been a part of Islam, and it can trace to 
the pre-Islamic days in the Holy City of Mecca that has been the center of commercial activities. It was indeed the annual trading center of Mecca that provided Prophet Muhammad (PBUH) the forum for preaching Islam. The early Muslims were not only engaged in trade, but they went to distant lands in connection with the business. Islam, in fact, reached East Africa, West Africa, and East Asia through the business people. Islam encourages work in general, and trade and commerce in particular. Besides, the Qur'an thus includes rules not only for manners and hygiene, marriage and divorce, but it also lays down detailed rules for commerce and politics, interest and debts, contracts and wills, and industry and finance. Islam lays out the basic principles of economic behavior as consumers, producers, and owners of wealth. The Islamic principle in business based on individual enterprise and correspondingly individual's reward.

Similarly, from the perspective of the Christian faith, the intention for entrepreneurial activities can be the trail to the early pre-Christianity era. From within the scriptures (the Holy Bible), many Biblical figures are entrepreneurs, to name a few in the scriptures is Jesus, Apostles Peter, Andrew, John, James, and Paul; Lydia and Job (AYE Online, 2017). Before the age of thirty (30) when he actually began his ministry on earth, Jesus being the eldest son of Joseph learned and practice the act of carpentry from his father (Mark 6:3) in his city of Nazareth (Matthew 2:23; Luke 2:39), making chairs, tables, and other wooden crafts. Subsequently, Apostle Peter and Andrew were commercial fishermen, building a fishing business (Matthew 4:18); Apostle James and Apostle John (the sons of Zebedee) were also fishermen (Matthew 4:18) before Jesus Christ called them to the ministry to become the fishers of men (Matthew 4:19); Apostle Paul was a Sole Proprietor intent making business (Acts 18:3); Lydia the first convert to Christianity in Europe was a selfemployed merchant selling purple (Acts 16:14); and Job was a very industrious farmer with 7000 sheep, 3000 camels, 500 oxen and 500 donkeys (Job 1:3). Christians are thus generally instructed to work (1 Thessalonians 4:11), not to be lazy or idle (Romans 12:11; Matthew 25:18; Matthew 25:25) as it leads to poverty (see Proverbs 6:11; Proverbs 10:4; Proverbs 13:4; Proverbs 19:15; Proverbs 20:13; Proverbs 23:21; Proverbs 28:19). Overall, entrepreneurship can view as an act of creation which derived from being made in God's image (Colossians 3:23), having the ability to turn chaos into order and create value where others see nothing, beyond the creative impulse.

In understating the influence of religion on entrepreneurial intentions, the Theory of Planned Behavior (TPB) is most suitable. According to the theory, the emergence of intended behavior influenced by specific factors. The factors are personal attitude (a subjective assessment of an individual over a behavior), social norms (a person's perception that there is social pressure over performing a behavior or most likely the probability of people considered significant by an individual to approve, support or reject an activity) and perceived behavior control or perceived self-efficacy (the perception of the level of difficulty to perform or to realize an intended activities). In essence, behavior that appears systematically is viewed not to have come from the impulsive and spontaneous decisions, but it has gone through the following step of planning, establishment, and strengthening of individual intentions and mental readiness (Wibowo, 2017). During the intention formation process, the individual's beliefs (religion) are usually responsible for shaping the intention. 
On the basis of social norms, normative belief (religion) act as the inculcator of values and societal norms.

Although at the individual level, parental and other role models act as the driving force of specific behaviors, as it encompass a wide range of perspectives on ethical behaviour, corporate responsibility, environmental ethics and sustainability (Tracey, 2012), religion which identities are socially constructed encompassing broader cultural and social considerations which cannot confine to the individual (Beckford, 2003) is more likely to both intrinsically and extrinsically frame the behavior of individuals towards entrepreneurship. Religion may not necessarily explicitly promote or inhibit entrepreneurial activity, but instead may propagate particular cultural value systems in particular societal contexts, that in turn frame attitudes towards entrepreneurship (Henley, 2016). Since the Adherence to religion and its practices usually expose followers to new behavioural pattern which alters all their lifestyle in its ramifications (Nikolova and Simroth, 2013), the emergence of specific religious activities which places strong emphasis on building behavioral norms and on shared but distinct experience, is likely to have a critical role in stimulating and influencing entrepreneurial activities (Dodd and Gotsis, 2007).

Different religions have different values regarding wealth accumulation, innovating and taking active responsibility for one's fate (Zelekha et al. 2014). For instance, from the point-view of Islam, the way of doing Islamic business is inclusive in the Fiqh Muamalat, which is related to the social relationship between human and others inclusively (Abdullah et al., 2011). Hence discrimination between people based on their religion, sex, or gender is forbidden. Accordingly, the production, selling and purchasing of goods such as Alcohol and Drugs; transaction involving uncertainty (as this could lead to quarrel or litigation, although, such transactions are permissible if the element of uncertainty is tiny); hoarding to make higher profit at the cost of public interest (when it is needed, or so it will become needed), fraud in business dealings; buying or selling what is legal, if the intention to use illegally is known, such as weapons, drugs, etc.; and the payment and receiving of interest are highly condemned in Islam and are not permissible for Muslims to indulge. Likewise in Christianity, the teachings inculcated in the followers is to deal with their customers or partners righteously (Hosea 10:12; Luke 16:12; Philippians 4:8-9; 1 Corinthians 10:31), being impartial, just, abstinence from bribery and corruption (Deuteronomy 16:19), and nonindulgence in rivalry and conceit (pride). Though legitimate interest or usury is acceptable in the Christian faith (Matthew 25:27), excessive interest rate or lending to the poor with interest generally admonished (Exodus 22:25). Hence, the internal values of an entrepreneur drawn from his religion have a deep level of personal meaning on their entrepreneurial pursuits (Kinjerski and Skrypnek, 2004), this is because most people will not follow if the business activities are deterred by their religious belief (Audretsch et al., 2013). Most religion usually preaches hard work and steadfastness in doing right; the desire to earn more, the power of wealth acquisition (Isa and Shitu, 2015), hence convincingly stimulating an individual into entrepreneurial activities.

Empirically, both in developed and developing economies, quite a handful of research on the influence of religion on entrepreneurial intentions have undertake. For instance, Riaz et al., (2016) using cross-sectional data collected from the sample of 290 final year 
business students in private higher educational institutes of Pakistan empirically investigate the impact of Religion on entrepreneurial intentions in Pakistan. Employing the technique of Structural Equation Modelling (SEM), it discovered from the study that religion has a highly significant impact on Entrepreneurial Intention in Pakistan. Similarly, Deepika (2017) examined the impact of Religious diversity on entrepreneurial intentions using a macro data from Global Entrepreneurship Monitor (GEM), Association of Religious Data Archives and Hofstede's cultural index. Hence, employing the technique of multiple regression analysis, it was discovered that religious diversity influences entrepreneurial intention negative. Youcef et al. (2015) assessed the impact of Religious Dimension on Entrepreneurial Intention among youths in Algeria. Therefore, with the use of Partial Least Square (PLS) approach to analyze the micro cross-sectional data obtained from sampling 54 graduates with entrepreneurial thoughts from Saida, Algeria, the study revealed that the dimension of religion in the country positively influence entrepreneurial intention.

Abdullahi et al. (2017) examine the impact of Socio-Cultural factors (Education, Religion and Family background) in Business Environment on Entrepreneurial Intention. The study discovered that religion and family background significantly influences entrepreneurial intentions positively, while education is insignificant in influencing entrepreneurial intentions. Equally, Kothari (2013) studied the Impact of Contextual (demographic) Factors on Entrepreneurial Intention using a sample of 880 final year students of different colleges in Uttarakhand in conventional and professional courses. Therefore, employing descriptive statistics to capture the characteristics of the samples and Logistics regression model, the study discovered that religion and other contextual factors (gender, parental occupation, and family income) are indeed significant in influencing entrepreneurial intentions.

Mohammed et al. (2017) examined the Influence of Attitude, Subjective Norms and Perceived Behavior Control on Entrepreneurial Intentions among Algerian Students using a sample of 175 students from the University of Tlemcen, Western Algeria. Employing the technique of Structural Equation Modelling (SEM), the findings show that students' behavior or attitudes towards entrepreneurship and subjective norms (relating to influence from religious groups, family, peer groups, etc.), influences entrepreneurial intentions of students in Algeria positively. Furthermore, Wibowo (2017) examined the relationship between Religiosity and Entrepreneurial Intention in Indonesia with the use of the sample of 412 undergraduate students of the Faculty of Economics and Business, University of Indonesia. From the empirical result obtained using the technique of Structure Equation Modelling (SEM), the study revealed that, through personal behavior, social norms, and perceived selfefficacy were found to be the major determinants of entrepreneurial intentions, group of students that are religious has stronger personal attitude towards entrepreneurial activity than perceived self-efficacy compared to the irreligious group, because personal beliefs as well influence the variables that influenced entrepreneurial intentions about them. Finally, Asare-Kyire et al. (2016) examined the impact of Religion on gender Entrepreneurial performance in Ghana. Using Partial Least Square-Structural Equation Modeling (PLS-SEM) technique to analyze 257 SME owners that make up the sample, consisting of Full Gospel Businessmen Association and Aglow Women's Fellowship in Ghana, the result obtained by the study shows that religion significantly influence the performance of male entrepreneurs 
in terms of marital life and societal perception compared to female entrepreneurs. While inheritance system that forms part of the norm in the Sub-Saharan African community is insignificant in influencing entrepreneurship.

Explicitly, there exists no single accessible study that examines the influence of religion on entrepreneurial intentions in Nigeria. Most of the studies on entrepreneurial intentions in the country were either focused on the influence of specific behavioral control factors (Owoseni, 2014; Muhammad et al., 2015), socio-cultural factors (Abdullahi et al., 2017) and entrepreneurial intentions theoretically (Idris, 2017). Although the empirical study of Abdullahi et al. (2017) incorporated the influence of religion in its model, the influence of religion in the model was not treated as in Riaz et al. (2016), but most likely as a control variable. Similarly, employing the use of samples from those that are currently engaged in entrepreneurial activities (Kyire et al, 2016), the use of samples from final year students (Riaz et al., 2016; Abdullahi et al, 2017; Kothari, 2013) and undergraduate students (Mohammed et al, 2017; Wibowo, 2017) which make up most of the studies is likely to give misleading result and wrong representation of entrepreneurial intentions. Hence, this study will obviously examine the influence of religiosity on entrepreneurial intentions in Nigeria, and bridge the research gaps from previous studies by employing the use of samples from recent graduates of economics and business and those on the one year compulsory service (NYSC) to model entrepreneurial intentions as they are out of school recently and are likely to have entrepreneurial intentions obviously.

\section{METHOD}

This study conduct through the survey of 100 recent graduates of business and economics at Ibrahim Badamasi Babangida (IBB) University Lapai, Niger State, Nigeria. The choice and target of recent graduates of Business Administration and Economics for this study is due to their exposure to business and entrepreneurship, and being at the critical stage of choosing a career option, hence the probability of intending to be an entrepreneur after graduation or after the one year compulsory national service scheme (NYSC). For empirical analysis a functional relationship is specified as follows:

$$
\text { ENTINT }=f(R E L)
$$

Where; $E N T_{I N T}$ denotes Entrepreneurial Intentions; and REL denotes Religiosity or the probability of being religious. Apart from religiosity, other factors such as occupational status of parents (whether an entrepreneur, labourer/employee or politician), personal attitudes towards entrepreneurship, social norms (family business background, friends, business people, etc.), and self-efficacy (ability to solve problems, make decisions, manage money, creativity, and being a leader) also influence entrepreneurial intentions.

Therefore Equation (2) can be re-written as:

$$
\text { ENTINT }=f(R E L, F A O C, \text { PATT, SNORM, SEFF) }
$$

Where: FAOC represents the occupational status of parents; PATT denotes personal attitudes towards entrepreneurship; SNORM is the societal norms, which shapes the entrepreneurial intentions of individuals; and SEFF denotes self-efficacy.

To empirically analyze the functional relationship in Equation (2) the Logistic (Logit) 
regression model will be employed. The choice of this model is guided by the dichotomous nature of the response variable (entrepreneurial intentions), taking the value of 1 if one have the intention of being an entrepreneur after graduation, and 0 if otherwise. The Logit model is specified as;

$P_{r}\left(E_{\text {ENTINT }}=\frac{1}{0}\right)=a_{0}+b_{1}$ REL $_{i}+b_{1}$ FAOC $_{i}+b_{2}$ PATT $_{i}+b_{3}$ SNORM $_{i}+b_{4}$ SEFF $_{i}+\mu_{i}$

Where $P_{r}\left(E_{\text {ENINT }}=\frac{1}{0}\right)$ denotes the probability of an individual having an entrepreneurial intention; $a_{0}$ is the intercept; $b_{1}-b_{4}$ are the parameter/coefficient of the explanatory variables in the model; and $\mu_{i}$ is the error term.

To measure entrepreneurial intentions, a simple closed-ended question on entrepreneurial intention with Yes/No, then Yes taking the value 1, and No taking the value 0. Religiosity or the extent at which one is religious was measured with the use of 6-item close-ended questions (such as the status of reading religious books, frequency, attending religious gathering, believe in hell and heaven, devotion to religion, etc.) on a 6-item Likert scale. The weighted average is then taken, individuals with weighted average above 4 are assumed to be religious. Individual with weighted averaged below 4 on the 6-item Likert scale denotes that they are non-religious people. Parent's occupational status was measure with the use of close-ended question taking the value 1 if parent are entrepreneurs and 0 if otherwise; personal attitude towards entrepreneur, societal norms and self-efficacy was measured in the same manner as religiosity, with corresponding close-ended questions.

\section{RESULT AND DISCUSSION}

This study observed 100 respondents with entrepreneurial intention. From the result of the descriptive statistics presented in Table 1, entrepreneurial intentions consist of having the entrepreneurial intention and not having. Out of the 100 observations, 77 respondents have the intention of being entrepreneurs, while 23 do not intend to be anything near entrepreneur. The mean of entrepreneurial intention is 0.77 , with a corresponding difference of 0.42 , and this shows the majority of the respondents having the intentions of being entrepreneurs. Although usually hindered by specific socio-economic and financial factors, the majority of youth in Nigeria prefer to be entrepreneurs due to the inability of the governments at each to create jobs for the population, and the widespread of unemployment in the county.

The religiosity status of individuals cannot be directly measured or ascertained. Hence, the use of close-ended questions such as the reading of holy books corresponding to the religion practiced, the frequency of reading the holy book, attending religious services and gathering, devotion to religion and belief in the existence of God, heaven, hell, and eternity (since the major religious groups preach these). The question then subjected to Likert scaling and Weighted Average (WA) technique, then respondents with the point above four are considered religious. From the observations, out of 100 respondents, while 66 respondents are considered religious, the remaining 43 respondents are considered non-religious. Religious individuals being the majority compared to the irreligious groups are likely because most of the respondents practice Christianity and Islam (44 and 44 respondents respectively). Very few respondents practice the traditional religious and other religion (5 and seven respondents respectively). 
Table 1: Descriptive Statistics

\begin{tabular}{|c|c|c|c|c|}
\hline Variables & Obs. $=100$ & Mean \pm SD & Min & Max \\
\hline \multicolumn{5}{|c|}{ ENTREPRENEURIAL INTENTION } \\
\hline Have & 77 & $0.77 \pm 0.42$ & 0 & 2 \\
\hline Don't Have & 23 & & & \\
\hline \multicolumn{5}{|l|}{ RELIGIOSITY STATUS } \\
\hline Religious & 66 & $0.66 \pm 0.48$ & 0 & 1 \\
\hline Non-Religious & 34 & & & \\
\hline \multicolumn{5}{|l|}{ RELIGION } \\
\hline Christianity & 44 & & & \\
\hline Islam & 44 & $2.25 \pm 0.85$ & 0 & 3 \\
\hline Traditionalist & 5 & & & \\
\hline Others & 7 & & & \\
\hline \multicolumn{5}{|l|}{ GRADUATE STATUS } \\
\hline Graduate & 59 & $1.59 \pm 0.49$ & 1 & 2 \\
\hline Undergraduate & 41 & & & \\
\hline \multicolumn{5}{|c|}{ PARENT'S OCCUPATION } \\
\hline Entrepreneurship & 44 & & & \\
\hline Labourer/Employee & 30 & $1.86 \pm 1.14$ & 0 & 3 \\
\hline Politician & 12 & & & \\
\hline Others & 14 & & & \\
\hline \multicolumn{5}{|c|}{ WHY ENTREPRENEURSHIP? } \\
\hline Freedom & 10 & & & \\
\hline Riches/Wealth & 19 & $2.81 \pm 0.87$ & 0 & 4 \\
\hline Self-Employment & 51 & & & \\
\hline Others & 20 & & & \\
\hline
\end{tabular}

Source: Author's Computation 2018

The occupation of parents being a significant factor influencing the entrepreneurial intentions of individuals is divided into four (4), with parents of 44 respondents being an entrepreneur, 30 being employee (civil servant), 12 being politician and 14 engaged in other activities. The average of respondent's parent occupation being 1.86 with the difference of 1.14. It's denotes the majority of entrepreneurship practice among the parents of the respondents, hence likely to be factor behind the entrepreneurial intention, or the decision to be entrepreneurs after graduation/National Youth Service Corps (NYSC), as the respondents is made up of recent graduates awaiting placement for NYSC and those currently on the scheme (59 respondents and 41 respondents respectively). Apart from the occupation of parents, factors such as the desire for freedom, riches, and self-employment also influence the decision to be an entrepreneur. Although the majority of the respondents are influenced by the desire for self-employment (51 respondents), while others desire to be entrepreneurs so they can be independent/freedom and riches (10 respondents and 19 respondents).

The Logistics regression model presented in Table 2 follows the empirical model of the influence religiosity (and other factors) on entrepreneurial intention in Equation (3), the response variable based on the binary response, with the large percentage of the respondents having the intention to be entrepreneurs. However, as a measure of goodness of fit, Pseudo R2, link test (_hatsq) and Log Likelihood Ratio (LR) indicates that the logistic model is correctly specified.

Religiosity shows a positive impact on entrepreneurial intention, indicating that religiosity 
is highly essential in determining entrepreneurial intention during the intention formation process. This result implies that a unit increase in religiosity will likely increase the log of the odds ratio by 1.56. Just, it means that the more religious an individual is, the more likely that individual may embrace the entrepreneurship, this is because religion apart from being a critical factor in the shaping of individual's personality, it is also one factor that often determines the social activities of individuals, hence once religion embraced and its virtues upheld, it overhauls the mindset of the individual. The positive influence of religiosity on entrepreneurial intention corroborates with previous empirical studies (Abdullahi et al., 2017; Kothari, 2013; Riaz et al., 2016; Samuel et al. 2013; Sihombing, 2016).

The probability of family's business background or parent's occupation being entrepreneurship has a negative influence on entrepreneurial intention, although not significant, this is because the majority of the respondents are from families whose parents are entrepreneurs. This result, therefore, entails that for a unit change in the probability of being from a family of entrepreneurs, the log of the odds of the ratio will decline by 0.22. This result differs from the empirical findings of Samuel et al. (2013), Abdullahi et al. (2017), and Kothari (2013). Personal attitude towards entrepreneurship shows a positive effect on entrepreneurial intentions, indicating that units increase or decrease in personal attitude towards entrepreneurship will lead to 1.94 increase or decrease in the log of the odds ratio. This result validates the empirical findings of previous research (Sihombing, 2016; Samuel et al., 2013; Muhammad et al., 2015; Mohammed et al., 2017).

Table 2: Logistics Regression Result Dependent Variable: ENTINT

\begin{tabular}{ccccc}
\hline Variable & Coefficient & z-statistics & Prob. (z-stat) & dy/dx (Marginal Effect) \\
\hline Constant & -4.702614 & -2.43 & $0.015^{*}$ & - \\
REL & 1.559638 & 1.73 & $0.083^{* * *}$ & 0.1560601 \\
FAOC & -0.2196714 & 0.26 & 0.795 & -0.0177671 \\
PAAT & 1.942624 & 3.99 & $0.000^{*}$ & 0.152747 \\
SNORM & 1.965908 & 3.15 & $0.002^{*}$ & 0.1545777 \\
SEEF & -1.577014 & -2.19 & $0.028^{* *}$ & -0.1239994 \\
\hline
\end{tabular}

$\mathrm{N}=100$, Pseudo $\mathrm{R}^{2}=0.4723$, Log Likelihood Ratio $X_{2}(5)=50.94$, Prob. $>X_{2}=0.0000$, _hat $=0.95(4.03)$, hatsq $=$ $0.04(0.44)$

Source: Author's Computation 2018

Furthermore, societal norms, which are the social pressures emanating from family members, peer groups, successful business people, mentor, etc. towards intending to be an entrepreneur and entrepreneurial intention are positively related and significant on a $1 \%$ significance level. This result shows that a unit increase in societal norms towards business and entrepreneurship will cause the log of the odds of entrepreneurial intention to increase by 1.97. This result as well corroborates with the empirical findings of Mohammed et al. (2017) in their study in Algeria, and the findings of Muhammad et al. (2015) in Nigeria. 
Perceived self-efficacy or perceived behavior control (the perception of the level of difficulty to perform or to realize planned activities) shows a negative association with entrepreneurial intention and significant at 5\%. This result indicates that a unit change in perceived selfefficacy will result in 1.58 change in the log of the odds. Although this result deviates from the empirical findings of previous studies (Mohammed et al., 2017; Muhammad et al., 2015; Owoseni, 2014; Samuel et al., 2013), when the tendencies of perceived difficulty to become an entrepreneur posed by capital, unfavorable business environment, etc. heightens, it tends to result to decline in entrepreneurial intentions.

The result of the logistic regression model presented in Table 2 also explains the marginal effect for each factor in respect to its effect on entrepreneurial intentions. From the marginal effect in Table 2, an increase in religiosity of individual will cause entrepreneurial intention to increase by $16 \%$. Furthermore, changes in the probability of parents being an entrepreneur, personal attitude towards entrepreneurship, and the influence of societal norms towards entrepreneurship will cause entrepreneurial intentions to increase by $0.18 \%$, $15 \%$, and $16 \%$ respectively. While the increase in perceived self-efficacy tend to cause, entrepreneurial intentions to decline drastically by $12 \%$.

\section{CONCLUSION}

Furthermore, societal norms, which are the social pressures emanating from family members, peer groups, successful business people, mentor, etc. towards intending to be an entrepreneur and entrepreneurial intention are positively related and significant on a $1 \%$ significance level. This result shows that a unit increase in societal norms towards business and entrepreneurship will cause the log of the odds of entrepreneurial intention to increase by 1.97. This result as well corroborates with the empirical findings of Mohammed et al. (2017) in their study in Algeria, and the findings of Muhammad et al. (2015) in Nigeria. Perceived self-efficacy or perceived behavior control (the perception of the level of difficulty to perform or to realize planned activities) shows a negative association with entrepreneurial intention and significant at 5\%. This result indicates that a unit change in perceived selfefficacy will result in 1.58 change in the log of the odds. Although this result deviates from the empirical findings of previous studies (Mohammed et al., 2017; Muhammad et al., 2015; Owoseni, 2014; Samuel et al., 2013), when the tendencies of perceived difficulty to become an entrepreneur posed by capital, unfavorable business environment, etc. heightens, it tends to result to decline in entrepreneurial intentions.

The result of the logistic regression model presented in Table 2 also explains the marginal effect for each factor in respect to its effect on entrepreneurial intentions. From the marginal effect in Table 2, an increase in religiosity of individual will cause entrepreneurial intention to increase by $16 \%$. Furthermore, changes in the probability of parents being an entrepreneur, personal attitude towards entrepreneurship, and the influence of societal norms towards entrepreneurship will cause entrepreneurial intentions to increase by $0.18 \%$, $15 \%$, and $16 \%$ respectively. While the increase in perceived self-efficacy tend to cause, entrepreneurial intentions to decline drastically by $12 \%$. 


\section{REFERENCES}

Abdullah, J., Asharaf, M. R., \& Syahidawati, S. (2011). The Four Introductory Theories of Fiqh Muamalat. Nilai: Wisdom Publication.

Abdullahi, A. I., Zainol, F.A., Daud, W. N. W., \& Yazid, A. S. (2017). Entrepreneurial Intention Revisited: Measuring the Impact of Socio-Cultural Business Environment using Structural Equation Modeling. World Applied Sciences Journal. Vol. 35(8): 1445-1456. doi: https:// doi.org/10.5829/idosi.wasj. 2017.1445.1456.

Alkire, S. (2006). Religion and development. In Clarke, D. A. (Ed.). The Elgar Companion to Development Studies. Cheltenham: Edward Elgar.

Asare-Kyire, L., He, Z., Owusu, A., \& Junaid, D. (2016). Religious Impact on the Performance of Entrepreneurs: A Comparative Study of Male and Female in Sub-Saharan Africa. European Journal of Business and Management. Vol. 8(35): 85-91.

Audretsch, D. B., Boente, W. \& Tamvada, J. P. (2013). Religion, Social Class, and Entrepreneurial Choice. Journal of Business Venturing. Vol. 28(6): 774-789.

AYE Online (2017). Biblical entrepreneurship - The purpose of a Christian entrepreneur. Africa's Young Entrepreneurs. Retrieved from https://ayeonline.org/2017/01/17/biblicalentrepreneurship-thepurpose-of-christian-entrepreneur-6/

Beckford, J. A. (2003). Social Theory and Religion. Cambridge: Cambridge University Press.

Bwisa, H. M., \& Ndolo, J. M. (2011). Culture as a Factor in Entrepreneurship Development: A Case Study of The Kamba Culture of Kenya. Opinion. Vol. 1 (1): 20-29.

Deepika, D. R. (2017). Religious Diversity and Entrepreneurial Intentions: A Macro-level Analysis. (Unpublished Thesis). Kristiansand: University of Agder.

Deneulin, S., \& Rakodi, C. (2011). Revisiting Religion: Development Studies Thirty Years On. World Development. Vol. 39(1): 45-54. doi: https://doi.org/ 10.1016/j. worlddev.2010.05.007.

Dodd, S. D., \& Seaman, P. T. (1999). Religion and Enterprise: An Introductory Exploration. Entrepreneurship Theory and Practice. Vol. 23(1): 71-86. doi: https://doi. org/10.1177/104225879802300104.

Dodd, S. D., \& Gotsis, G. (2007). The Interrelationships Between Entrepreneurship and Religion. The International Journal of Entrepreneurship and Innovation. Vol. 8(2): 93104. doi: https://doi.org/10.5367/000000007780808066.

Henley, A. (2016). Does Religion Influence Entrepreneurial Behaviour? International Small Business Journal. Vol. 35(5): 597-617. doi: https:// doi.org/10.1177/0266242616656748

Isa, A., \& Shitu, S. (2015). Impact of religion on entrepreneurial intention of university students in Kano state, Nigeria. Proceedings of ICIC2015-International Conference on Empowering Civilization in the 21st Century.

Khraim, H. (2010). Measuring Religiosity in Consumer Research from an Islamic Perspective. International Journal of Marketing Studies. Vol. 2(2): 166-179.

Kinjerski, V. M., \& Skrypnek, B. J. (2004). Defining Spirit at Work: Finding Common Ground. Journal of Organizational Change Management. Vol. 17(1): 26-42. doi: https://doi. org/10.1108/09534810410511288. 
Kothari, H. C. (2013). Impact of Contextual Factors on Entrepreneurial Intention. International Journal of Engineering and Management Research. Vol. 3(6): 76-82.

Oukil, M. S. (2013). Entrepreneurship and Entrepreneurs in an Islamic Context. Journal of Islamic and Human Advanced Research. Vol. 3(3): 115-130.

Mohammed, B. S., Fethi, A., \& Djaoued, O. B. (2017). The Influence of Attitude, Subjective Norms and Perceived Behavior Control on Entrepreneurial Intentions: Case of Algerian Students. American Journal of Economics. Vol. 7(6): 274-282. doi: https:// doi.org/10.5923/j.economics.20170706.02

Muhammad, A. D., Aliyu, S., \& Ahmed, S. (2015). Entrepreneurial Intention among Nigerian University Students. American Journal of Business Education. Vol. 8(4): 239-248.

Nikolova, E., \& Simroth, D. (2013). Does Cultural Diversity Help or Hinder Entrepreneurs? Evidence from Eastern Europe and Central Asia. Working Paper No. 158. London: European Bank for Reconstruction and Development.

Owoseni, 0. 0. (2014). The Influence of Some Personality Factors on Entrepreneurial Intentions. International Journal of Business and Social Science. Vol. 5(1): 278-284.

Riaz, Q., Farrukh, M., Rehman, S., \& Ishaqu, M. (2016). Religion and Entrepreneurial Intentions: an Empirical Investigation. International Journal of Advanced and Applied Sciences. Vol. 3(9): 31-36.

Samuel, Y. A., Ernest, K., \& Awuah, J. B. (2013). An Assessment of Entrepreneurship Intention Among Sunyani Polytechnic Marketing Students. International Review of Management and Marketing. Vol. 3(1): 37-49.

Safiek, M. (2009). Relevancy and Measurement of Religiosity in Customer Behavior Research. International Business Research. Vol. 2(3): 75-84.

Sihombing, S. 0. (2016). Does Religious Values Matters in Prediction Youth Entrepreneurial Intention? An Empirical Study in Indonesia. The Social Sciences. Vol. 11(6): 7325-7329.

Tiwari, P., Bhat, A. K. \& Tikoria, J. (2017). An Empirical Analysis of The Factors Affecting Social Entrepreneurial Intentions. Journal of Global Entrepreneurship Research. Vol. 7(9): 1-25. doi: https://doi.org/ 10.1186/s40497-017-0067-1.

Tracey, P. (2012). Religion and Organization: A Critical Review of Current Trends and Future Directions. The Academy of Management Annals. Vol. 6(1): 87-134.

Valliere, D. (2008). Exploring Buddhist Influence on The Entrepreneurial Decision. International Journal of Entrepreneurial Behavior and Research. Vol. 14(3): 172-191.

Weber, M. (1922). The Theory of Social and Economic Organisation. New York: The Free Press.

Wibowo, B. (2017). Religiosity and Entrepreneurial Intention. Etikonomi. Vol. 16(2): 187-206. doi: https://doi.org/10.15408/etk.v16i2.4963.

Youcef, S., Djelloul, C., \& Mokhtar, I. (2015). The Impact of Religious Dimension on Entrepreneurial Intention by Using PLS Approach - Case Study. Economics World. Vol. 3(5-6): 137-144. doi: https://doi.org/10.17265/2328-7144 /2015.0506.003.

Zelekha, Y., Avnimelech, G., \& Sharabi, E. (2014). Religious Institutions and Entrepreneurship. Small Business Economics. Vol. 42(4): 747-767. doi: https://doi.org/10.1007/s11187013-9496-6. 